\title{
The Socioeconomic Sphere of Muslim Women A Critical Study on John l. Esposito's Views
}

\author{
Yāsir Farooq \\ Lecture Islāmic Studies, Govt. Postgraduate College, Jaranwālā, Pakistan \\ yasirfarooq797@gmail.com \\ Dr. Inām Ullà'h Wattū \\ Assistant Professor \\ Department of Islämic Studies, The University of Lahore, Pakistan \\ Email:Inam.ullah@ais.uol.edu.pk
}

\begin{abstract}
:
John L. Esposito categorized the status of Muslim women into two spheres; Ethico religious and socioeconomics. In religious ethic men and women are equal but in socioeconomic sphere rights of women are affected in three fields i.e priority of male over female, right of divorce and polygamy. He described that man's priority over women is due to his responsibilities of expenditure on women. As now in 21st century women are educated and participating in different fields of life so they are earning money. In this context men's priority over women is subject to change. But priority of man over woman is not only based on physical maintenance of household but also due to the difference in physical structure and mental approach between the two genders. These are main factors behind this priority syndrome which are well documented in the Holy Qur'an which is not subject to change. In the matters of divorce and polygamy he recommended some legal reforms which already exist in many Muslim countries as in the case of divorce men and women have equal rights. He suggested that man's right of extra judicial divorce should be banned. Both husband and wife should appear before court for divorce. Polygamy is already permissioned with the conditions of equal justice in finances as well as love and affection. But he recommends that if a married man wants to take another wife he should appear before a court to justify his position and make a pledge to treat all his life partners equally.
\end{abstract}

Keywords: Socioeconomics, Pagan, Rights, Polygamy, Divorce.

\section{Introduction}

John L. Esposito, a professor of Islämic Studies and international affairs at Georgetown University, belongs to a Roman Catholic family. He 
is the director of Al Waleed Bin Taläl Centre for Muslim-Christian Understanding at Georgetown University. He wrote many books and articles on Islām. One of his familiar books is "Women in Muslim Family Law". This book includes four chapters. Its fourth Chapter is "A Legal Methodology for Reform". In this chapter he discusses the needs of reforms as per the status of Muslim women and categorizes the status of women into two spheres, ethico-religious and socioeconomic sphere. Ethico-religious means $\bar{I} b \bar{a} d a t$, (prayers) and socioeconomic means Mūamilàt (social relations, Transactions). He says that there are some gearing contradictions in the status enjoyed by women and gender equality maintained yet these contradictions can be resolved by an analysis of different relevant verses of the Holy Qur'ān. He writes:

"Verses from the Qur'ān have been used by different factions

to both support a woman's subservience to man and to defend her rights of equality",

About the ethico-religious sphere he says that men and women are equal as the religious obligations toward Allah are same and so are the rewards and punishments for both sexes in the life hereafter.

This is what the Muslim Scholars also claimed about the equality of men and women. As Allah Almighty states in the Holy Qur'ān:

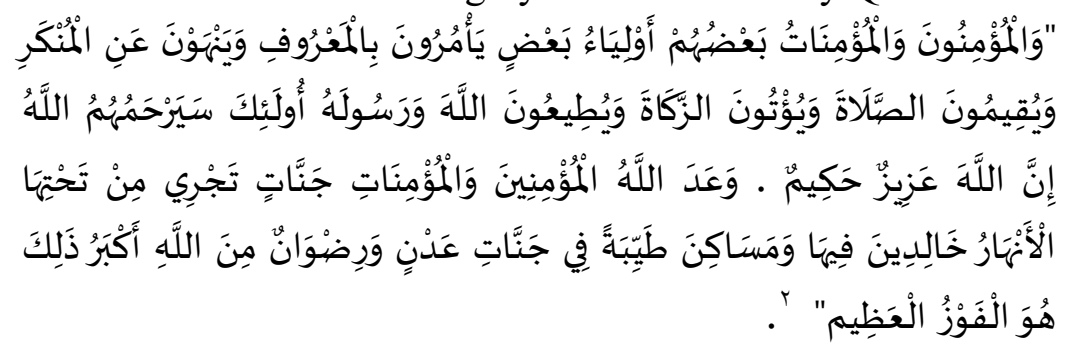

In the socioeconomic sphere he quotes different verses from the holy Qur'ān, In the light of these verses he highlights some inequalities are in common practice as for as the status of Muslim women go and suggests the following reforms in order that these inequalities are redressed:

1. Priority of Males over Females

2. Right of divorce

3. Polygamy

In the thesis under review we will analyze critically Esposito's views on the above stated inequalities in the following points: 


\section{Priority of Males over Females:}

About the priority of men over women he says men are superiors to women, which is a social inequality in the eyes of the Muslim women. In this regard he quotes a verse from the holy Qur'ān:

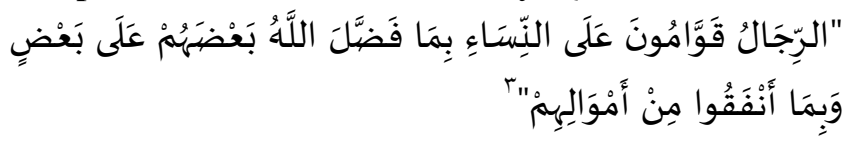

1.1 He says that it is the need of time that this priority should be reconsidered and makes the following comments on this verse:

"However the "priority" attributed to men over women is best understood as originating from their greater responsibility as protectors and maintainers within the socioeconomic context of Arabian society during the Prophet's time,",4

1.2 According to him men's priority over women is mere due to maintenance factor. It was suitable as far as the age of prophet was concerned when men were considered as protectors and maintainers in Arab society. But now in $21^{\text {st }}$ century women are educated and working in different fields of life and they are earning money, so they do not need to depend on men for maintenance. He recommended that men's priority over women should be reformed.

"However, when the social situation of women changes, as it has for no longer necessarily be dependent upon their husbands for maintenance and protection. Consequently, the concept of "priority" of husband over wife in the socioeconomic sphere is subject to change."

1.3 In the above mentioned Qur'ānic verse men are considered as guardians, maintainers, protectors and superiors to women as derived

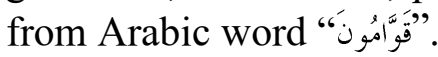

1.4 What is the truth about this priority? It needs to be looked into from different perspectives. Firstly the meaning of the word قَوَّمُونَ and its different explanations by different Muslim theologians, Secondly, its general meanings and necessity of priority granted to men over women.

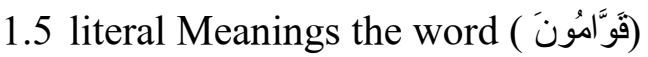

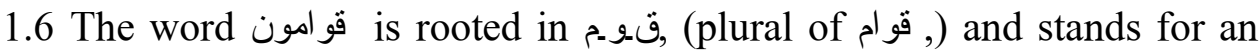
administrator, ruler, maintainer and protector in Arabic.

1.7 Men are administrators over women as they control and civilize them and this duty has been assigned to husbands by Allah as they are superiors to women as far as their opinion and wisdom are concerned. 


$$
\begin{aligned}
& \text { "الرجال قوامون على النساء)يعني أهل قيام على نساءهم ، في } \\
& \text { تأديبهن ، والأخذ على أيديهن ، فيما أوجب الله لهم عليهن.( فضل الهيل } \\
& \text { الله بعضهم على بعض) يعني في العقل والرأي." }
\end{aligned}
$$

He has been appointed as manager of the households to tackle the matters by planning and introducing reforms where necessary according to his understanding as he is capable of displaying wisdom, patience and knowledge as compared to women.

$$
\begin{aligned}
& \text { "وَهُوَ الْقَائيم بالمصالح وَالتَّدْبِير، ( فضل الله بعضهم على بعض) يَعْني: }
\end{aligned}
$$

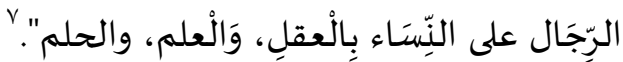

Men are authorized with the right to teach manners to women by the teachings of Islām in order that a discipline and respectful way of life is concerned.

$$
\text { "مسلّططون على تأديب النساء في الحق. إذا كانوا رجالا."^ }
$$

Men are protectors of women and they are responsible for all household matters like maintenance and overall the protection of the family as a ruler of a state is responsible for the welfare, maintenance and protection of his subjects.

$$
\text { "الرِجِالُ قَوَّامُونَ عَلَى النِّسـاءِ يقومون عليهن قيام الولاة على الرعية". }
$$

As a leader and supervisor husband is responsible for the welfare of his wife children and in case of disobedience and any disturbance whatsoever, he has to ensure order and good etiquettes.

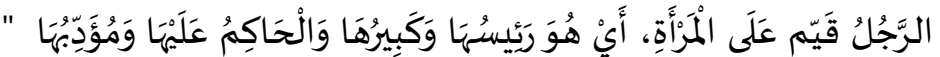

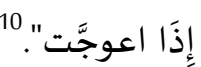

There is a sense of exaggeration in the combination of the words but delegation of authority to men in the divine words is un questionable and everlasting.

$$
\text { "الرّجِالْ قَوَّامُونَ صيغة مبالغة، ومجيء الجملة الاسمية لإفادة }
$$

1.81 .2 Necessity of men's priority over women:

1.9 The holy Qur'ān declared domestic life a basic unit of society headed by man and the word "قوام" makes it very clear. It is the one who supervises and manages the family matters. $\mathrm{He}$ is appointed administrator of household in order to run the system smoothly. Man's appointment as an administrator is due to two reasons: Firstly man is physically and mentally stronger by birth than woman; Secondly he is responsible of the maintenance of his wife and children. 
1.10 Best trained citizens are required for the development of a civilized and viable society and home is the first training institute to serve this purpose, so in this context husband and wife play very important role as man being manager of external affairs and wife being responsible for internal domestic issues like fostering grooming and protection of children. The Prophet of Islām Hazrat Muhammad (SAW) said:

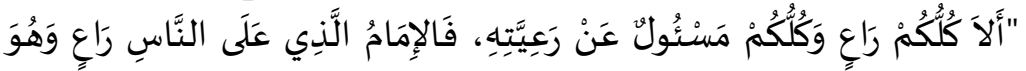

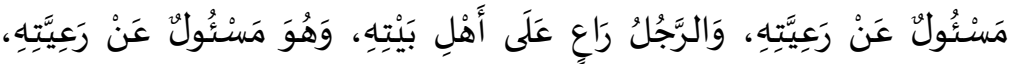

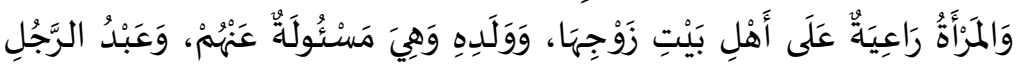

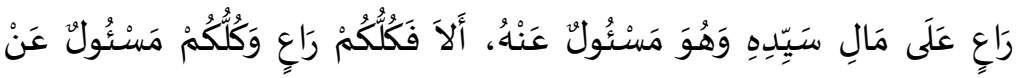

$$
\begin{aligned}
& \text { رَعِيَّتِهِه. }
\end{aligned}
$$

1.11 It is the duty of wife to serve her husband and bring up her children in a peaceful atmosphere. It is clear here that wife needs a tension free environment and best interference from outside if she has to focus on her children training and obviously she has been declared as queen of the household and husband is responsible for the most difficult tasks. It she steps beyond her limits and enters a zone where she has no role play, troubles shoot up and eventually this causes destruction of the family and Muslim society in general.

1.12 In this way she is declared house Queen and husband is responsible for all difficult matters. From the time when women is participating in man's responsibilities, it caused the disobedience of wives and children, destruction of family system and Muslim society.

\subsection{2.1. What makes man قوام (superior to woman)?}

1.14 Qawam (قو ام) means a guardian, head or administrator, so the person who has abilities to fulfil the social and financial responsibilities of others, can be regarded as Qawam, head or administrator of the household. The holy Qur'ān states two reasons to state God's preference to appoint man as administrator of household:

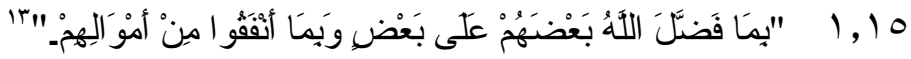

1.16 Because Allah has made one of them to excel the other and because they spend (to support them) from their means.

1.17 Firstly, according to the Holy Qur'ān Allah has made husband superior to his wife by physical structure, so he is able to carry out hard tasks which cannot be accomplished by woman. So demanding responsibilities cannot be assigned to women keeping in view their weak physique. There are many evidences from history where men performed many prominent deeds relating to different aspects of life 
and we are yet to witness any such deeds contributed by women whereas men are naturally fit for doing these hard tasks without any exaggeration.

1.18 Secondly, Allah has put all the responsibility of house expenditures on man as he is physically fit for making efforts earn a livelihood for the family while women are hardly capable to do it. So a woman has been made responsible for internal domestic matters. She is is entitled to decision making matters in domestic issues but as external matters are concerned, she has been assigned no role to play. She cannot be chosen as a caliph or head of state of Muslims. Some of the so called Islāmic thinkers impressed by western philosophy argued that women alongside men should participate in social matters and should be appointed as heads of state of Muslims whereas, the teachings of the prophet of Islām are very much clear in this regard:

$$
\text { 1, } 19
$$

1.20 As an argument for the authority of woman they referred to the story of Queen Balqees, who ruled over a state named Saba as mentioned in the Holy Qur'ān:

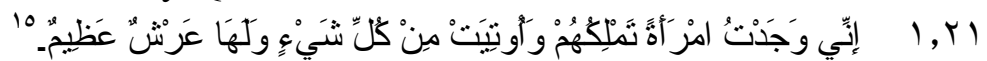

1.22 I have found a woman ruling over them, and all sorts of things are given to her, and she has a great throne.)

1.23 While presenting this evidence they tend to forget the fact that Queen Balqees of Saba was ruling the state of non-believers being herself a pagan. After embarrassing Islām, she relinquished everything to king Salomon and accepted his dominance and there is no evidence that she ever ruled any state again afterwards.

1.24 Some others even refer to the leadership of Hazrat Ayesha (R.A) in the war of Jamal (camel) as a precedent, but again it was a different situation entirely where she had to lead. In fact she had never ever demand the position of caliphate in her whole life time. In this incident Muslims were divided into two groups and she wished to make peace among them but the situation got worse unfortunately and led to the tragic incident for which she repented and felt upset afterwards. Her grace went to the extent that whenever she recited the verse وَقَرنَ في ${ }^{16}$ "بُيُوتِكنَ. From the Holy Qur'ān she wept bitterly:

\subsection{2.2. Necessity and importance of administrator}

1.26 The Arabic word قو ام stands for a person who provides necessities of life, maintains peace, introduces reforms and provides security. As an army has a commander and a state has a ruler to stabilize the system 
and smoothly run the affairs. So the stability and maintenance of a system requires obedience to commander and to ruler. Likewise a household also needs to be led by someone who will take the responsibility of ensuring prosperity and provide necessities of life. This can only happen if the members of the family offer their unquestioning obedience.

1.27 Since home is a basic unit of society, it requires to be administrated like a state in order to run it smoothly and take decision for the welfare of the household members as a state looks after its citizens and takes decision to guarantee their welfare. A better ruler chosen by people is responsible for the welfare of the society. It works exactly the same way when a household is ruled by a good administrator..

\subsection{2.3. Who can administrate a home properly?}

1.29 In the light of the above discussions it is very clear that home is also a micro state and like all other social institutions, demands proper administration. Now the question arises that who is the most suitable person for this responsibility. Obviously, it is either the father or the mother. The Holy Qur'ān delegates this authority to the father on account of two dominant qualities: one bestowed by Allah and second achieved by his own efforts. First undeniable quality bestowed upon him by Allah almighty, is his physical structure, wisdom and the ability to think seriously. Secondly he manages the financial expenditures of his family. So comparatively men are more suitable for the responsibilities of complex external matters and likewise women are responsible to administrate internal domestic affairs.

\subsection{2.4. Equal Status}

1.31 It must be borne in mind that the administration of a household does not mean a relegation of women's status or position and neither it effects the equality between both genders any way rather it is due to the differences in the nature of work they are capable to do as per their physical structures, so there is no comparison between the two as far as mental or physical faculties are concerned. It is a divine arrangement while cannot be questioned while Allah Almighty has ordained. It a son shows obedience to father, that does not lower his position as equal human beings. Almost every religion recognizes the superior role of father and when every society and household is ruled by this universal principle being a common value. Hence the factor of male dominance in the household does not affect their rights as husband and wife.

1.32 In the light of the above discussion it is concluded that the priority of males over females is quit justified and does not affect 
equality. Moreover, the Qur'ānic commandments are not subject to change. The holy Qur'ān is universal book and its guidance is also universal beyond any doubt which is implementable in any every time and space.

1.33 We cannot change or reform the Qur'ānic commandments. They are meant to be acted upon till the end of time. They are for all times and places. The statement that these rules are not implementable in every society is based on misconception and deliberate distortion of facts. The problem is that we do not want to change our evil ways old practice moral values, thus heading to a total disaster. We cannot blame the rule of nature for our wrong doings or hold responsible for our ills.

\section{Right of divorce}

1.34 Some even say that women are affected by divorce and polygamy, hence legal reforms are required. In the light of the Qur'ânic teachings men and women have equal rights as far as divorce is concerned. As Allah almighty says in the holy Qur'ān:

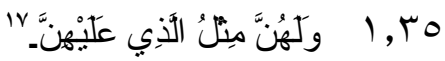

(And women shall have rights similar to the rights against them)

1.36 This verse recognizes the equal rights of women as divorce is concerned, it is not only men are authorized for divorce:

"No Qur'ānic verse supports the license of divorce presently awarded to males",18

In the next paragraph there is an evidence from the traditions of the Holy Prophets (SAW), in which a woman comes to the Prophet and askes about her rights for marriage:

"A girl came and stated that her father had given her in marriage and told her to wait till the Prophet arrived. When the Prophet came, I told him the full story of the girl. He at once sent for the father of the girl an inquired of him whether the fact stated were true, after which he told the girl that she was at liberty to choose or repudiate her husband. The girl replied saying that she chose to retain her marriage, and that she wanted only to know whether women had any rights in the matter. "19

And a tradition of Thabit bin Qais, in which her wife complained about him and said that they could pull together. On this Hazrat Muhamad(SAW) ordered him to leave her: 
"The wife of Thabit bin Qais, Habibah bint Sahil. . . told the Prophet 'I and Thabit cannot pull together.' When Thabit came to the Prophet said to him: this is what your wife says about you, so leave her." 20

After citing these traditions it can be claimed that man and woman have equal rights in the matter of divorce and suggested that man should be banned from exercising extra judicial divorce:

"A strong case can be made for establishing equal divorce rights by taking away the male's extra judicial rights of repudiation and equalizing the option to exercise divorce by requiring that all divorce suits be subject to the courts as has been in a number of Muslim countries." 11

Both in text and practice woman have equal rights for dissolution of marriage. Registration system for divorce has also been introduced in many Muslim countries. The suggested method for dissolution of marriage for the rights of women is already in practice.

\section{Polygamy}

According to author John L. Esposito the rights of women are affected by the second or third marriage of her husband even in the presence of first wife. He himself admit the fact that the Holy Qur'ān had introduced reforms in pre-Islāmic Arabian era by restricting the prevalent practice and limiting the number of wives permitted a man to four. But even this permission was contingent upon the just treatment of each wife. As the Holy Qur'ān stated:

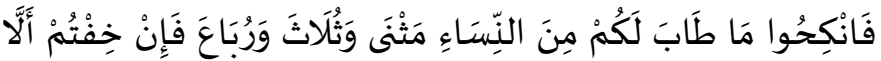

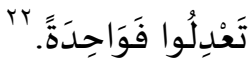

"Marry women of your choice, two, three or four.

But if ye fear ye shall not be able to deal justly then only one"

For restricting polygamy in modern times this Qur'ānic value of equal justice can be used. He suggest that if a married man wants to take another wife he should apper before a court and prove his ability to treat justly both:

"A similar approach has been used in drafting legal regulation which require a married man who wishes to take another wife to demonstrate to the court his ability to treat his wives equally in terms of finance as well as love and affection" 23

In the next paragraph he presents the idea that the Qur'annic order mentioned in chapter $4: 3$, that absolute prohibition of polygamy may be 
subjected to the requirement of impartiality and the impossibility of its full realization today. Qur'ānic support for this contention is also available:

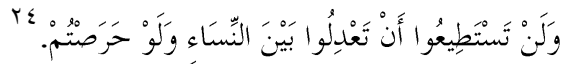

"You are never able to be fair and just as between women, even if it is your ardent desire"

His suggested reforms in the matter of polygamy are well documented in all the textual efforts of Muslim jurists. It is permitted with the condition of justice and equality. In case if he is not able to maintain justice among his wives he is not allowed to take a second wife in the presence of the first.

\section{Conclusion}

John Esposito categorized the status of women into two spheres, ethico-religious and socioeconomic sphere. Ethico-religious mean İbädat, and socioeconomic mean Müammlät. In ethico-religious sphere men and women are equal. In the socioeconomic sphere he highlighted some inequalities in the status of Muslim women and suggested reforms for said inequalities which are as following. Priority of Males over Females, Right of divorce and Polygamy. According to him men's priority over women is mere due to his maintenance, now in $21^{\text {st }}$ century women are educated and working in different fields of life, they are earning money. So there is no more need for women to depend on men for maintenance. $\mathrm{He}$ recommended that men's priority over women should be reform. According to the Holy Qur'ân Allah has made husband excel to his wife, by physical structure men are stronger than women so they can work more hard than women. Moreover men have extra abilities to perform hard tasks and responsibilities. Allah has made the men responsible for all the expenditures of his family members. The priority of males over females is quite justice and did not mean any inequality, moreover Qur'ānic orders are not subject to change, the Holy Qur'ān is a universal book and its guidance is also universal and implementable in every time and space.

Both in text and practice woman have equal rights for dissolution of marriage. According to author the rights of women are affected by the second or third marriage of her husband even in the existence of first wife. For restricting polygamy in modern times this Qur'ānic value of equal justice can be used. He suggest that if a married man wants to take another wife he should be present before court and prove his ability to treat justly with both. 


\section{References \& Endnotes}

1. Esposito, John Louis. Women in Muslim family law, SYRAUSE

University Press, New York 1982. Page\#107

2. Al-Quran 9:71-72

3. Al. Quran 4:34

4. Women in Muslim family law. Page\#108

5. Women in Muslim family law, page\#108

• · الماوردي، أبو الحسن علي بن محمد بن محمد بن حبيب البصري البغدادي، تفسير الملاوردي/ النكت

و العيون، دار الكتب العلمية - بيروت / لبنان، ج اص •ــ

السمعاني ،أبو المظفر، منصور بن محمد بن عبد الجبار ابن أحمد المروزى التميمي الحنفي، تفسير

القرآن كدار الوطن، الرياض - السعودية،11) (0)، ج إص سبع

الجوزي ،جمال الدين أبو الفرج عبد الرحمن بن علي بن محمد، زاد المسير في علم التفسير،دار الكتاب

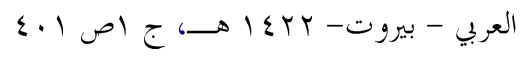

البيضاوي ،ناصر الدين أبو سعيد عبد الله بن عمر بن محمد الشيرازي، أنوار التزيل وأسرار

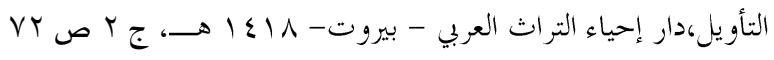

الدمشقي ،أبو الفداء إسماعيل بن عمر بن كثير القرشي البصري،تفسير القرآن العظيم ،دار طيبة

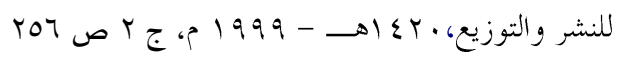

الزحيلي ،د وهبة بن مصطفى، التفسير المنير في العقيدة والشريعة والمنهج ،دار الفكر المعاصر - 
البخاري،محمد بن إسماعيل أبو عبدالله الجعفي،الجامع الصحيح، كتاب الاحكام، باب اطيعو الله....

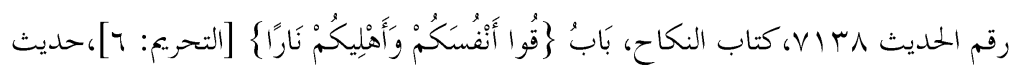

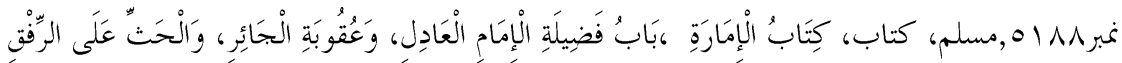

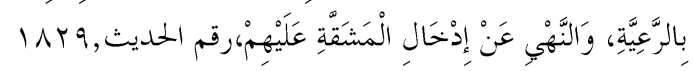

13. Al. Quran 4:34

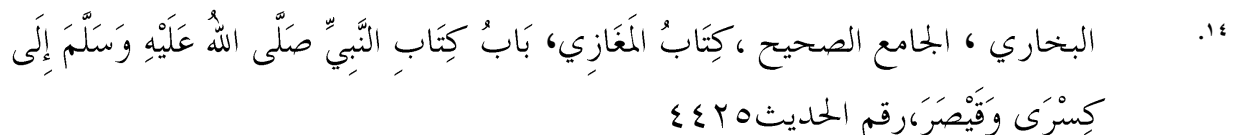

15. Al Quran 27:23

16. Al Quran 33:33

17. Al Quran 2:228

18. Women in Muslim family law, page\# 109

19. Women in Muslim family law, page\#109

20. Women in Muslim family law, page\#109

21. Women in Muslim family law, page\#110

22. Al Quran 4:3

23. Women in Muslim family law, page\#110

24. Al Quran 4:129 